\title{
Progression og innovation - hvordan kan de to begreber berige hinanden og universitetsundervisning?
}

Tine Lynfort Jensen, ph.d., adjunkt ved Institut for Sprog og Kommunikation, Syddansk Universitet.

\section{Reviewet artikel}

I denne artikel kobles begreberne innovation og progression til hinanden med afsæt $i$ forfatterens erfaringer med innovationsundervisning af humaniorastuderende. Sxrligt fokuseres der på kompetenceafklaring som en løftestang for sammenkoblingen, idet studerendes bevidsthed om egne ressourcer kan bidrage til progressionen $i$ undervisningsforløb. Der præsenteres en udviklet model med afsæt $i$ denne form for undervisning, hoor progressionsbegrebet søges forstået og forklaret på tre niveauer. Slutteligt diskuteres, hvorledes innovation og progression som begreber og som undervisningsaktiviteter kan berige hinanden på universiteterne generelt.

\section{Introduktion}

"Jeg bevæger mig fremad". Så kort og præcist kan progression beskrives, når den latinske betegnelse 'pro-gredior' anvendes (Leth, 2008). I en uddannelsesmæssig kontekst er der en tæt forbindelse til læring, idet progressionsbegrebet understøtter læringens betydning som en fremadrettet - og således opbyggende - proces (Hughes, 1996). Innovationsundervisning handler også om at lære studerende at bygge op. Her fokuseres på at udvikle nyt og dermed skabe værdi for sig selv eller andre i samfundet. Man undervises i innovation, og ikke kun om innovation (Darsø, 2011). Politiske strømninger er med til at sætte dagsordenen for, hvilke pædagogiske og didaktiske bevægelser der fokuseres på i uddannelsessystemet. Innovation og entreprenørskabsundervisning har siden 2005 været et fokusområde i dansk uddannelsespolitik, hvor først det nationale center for entreprenørskab, IDEA, og siden Fonden for Entreprenørskab er blevet centrale aktører i indsatsen for at uddanne unge i innovation og entreprenørskab (VTU, 2010; MIVU, 2012; Krill, 2012). Senest har den siddende regering lavet en innovationsstrategi, som skal sikre, at elever og studerende får kendskab til fænomenet ud fra antagelsen om, at evnen til at omsætte teori til nyskabende praksis er vigtig på fremtidens arbejdsmarked (FIVU, 2012). 
Denne artikel forsøger at skabe forbindelser mellem progression og innovation i teori og praksis for at imødegå to af de opgaver, som uddannelsessystemet står overfor: Hvordan kan man integrere innovationsfag på de videregående uddannelser, og hvordan kan man øge progression i undervisningen?

Artiklens påstande er, at man kan øge integrationen ved at arbejde med progression gennem kompetenceafklaring, at innovationsundervisning netop kan være en løftestang for arbejdet med progression og kompetenceafklaring, og at studerendes læring og oplevelse af sammenhæng i studiet dermed generelt kan øges ved at tænke innovation og progression sammen.

Forskning peger på, at studerendes bevidsthed om ressourcer og kompetencer kan understøttes af innovation og af entreprenørskabsundervisningsfeltet, fordi det i høj grad anvender undervisningsformer, der sætter den studerendes aktive bearbejdning af viden i fokus (Leth, 2008). Den aktive bearbejdning fordrer en øget bevidsthed hos de studerende om personlige kompetencer og faglighed, som så kan anvendes til nyskabende praksis (Bager \& Blenker, 2008; Jensen, 2011; Lynfort, 2012).

\section{Undervisningskontekst og metode}

På Humaniora på Syddansk Universitet har man på bacheloruddannelserne i International Virksomhedskommunikation de sidste 8 år undervist i gennemsnit 80 studerende årligt $i$ et obligatorisk innovationsfag på 4. semester, hvor de i teams på 3-5 personer skal udvikle, analysere og realisere en innovativ idé. Fagets titel er Innovation, projektledelse og teamsamarbejde. En innovativ idé kan i denne sammenhæng både være opstart af en ny virksomhed og udvikling af et nyt koncept for en eksisterende organisation, og det innovative "produkt" kan være teknologisk, kulturelt og socialt. Således opereres der med en bred forståelse af en innovation. Innovationerne beskrives gennem en projekt- eller forretningsplan, ved analyser og konkret udviklingsarbejde med idéen, samt ved sparring med undervisere og eksterne rådgivere. Undervisningen bestås ved aktiv deltagelse, hvor fokus er på at forsøge at realisere idéen ved at arbejde både teoretisk og handlingsorienteret med den. Der undervises således både om og i innovation.

Humaniora forbindes ofte ikke med innovation, selvom tidligere analyser viser, at humanistiske kendetegn blandt andet vurderes som kreativitet, alternative vinkler og evnen til at forstå trends og bevægelser i samfundet (Frølund et al., 2009; Jensen, 2010). Der ligger derfor en opgave for underviserteamet $i$ at forbinde innovationsfaget til resten af uddannelsen, hvor man primært beskæftiger sig med fagområderne sprog, kommunikation, kultur og organisation. 
I undervisningen lægges der derfor vægt på, at de studerende udvikler innovative idéer med afsæt i deres viden, faglighed og erfaringer. Bevidstheden om disse elementer er generelt ikke tydelig for de studerende. Derfor udgør kompetenceafklaring et grundelement.

I artiklen analyseres muligheden for at koble progression og innovation i teori og praksis med afsæt i erfaringerne med kompetenceafklaring i innovationsfaget. Først beskrives det læringsteoretiske udgangspunkt, hvorefter begreberne progression og innovation diskuteres. Dernæst beskrives kompetenceafklaringselementet i relation til de to begreber. Derefter illustrerer et skema, hvordan der arbejdes med kompetenceafklaring i faget. Efterfølgende præsenteres en model for, hvordan progressionsbegrebet kan tænkes sammen med kompetenceafklaring med afsæt i innovationsundervisning. Afslutningsvist diskuteres indholdet i relation til anvendelsesmuligheder i det danske uddannelsessystem. Der eksemplificeres med empiriske data fra mundtlige og skriftlige studenterevalueringer på 8 hold for årene 2011-2013 og kompetenceafklaring fra 2013 på innovationsfaget.

\section{Læringsteoretisk udgangspunkt}

Artiklens udgangspunkt er den konstruktivistiske læringsopfattelse, der er inspireret af både det kognitive og det sociokulturelle paradigme (Qvortrup \& Wiberg, 2013). Her er fokus på individets sociale konstruktion af læring gennem interaktion med andre i sociale kontekster. Læring er således en aktiv proces i og imellem mennesker, hvor vekselvirkningen mellem individ og det sociale er afgørende for at forstå, hvordan vi lærer. Det konstruktivistiske læringssyn ser på læring fremfor indlæring, og det betoner erfaringsdannelse som en aktiv og reflekteret proces.

Det konstruerende afsæt korresponderer med teorierne fra innovations- og entreprenørskabsundervisning, hvor det aktive handlingselement og studerendes evne til at konstruere nyt i en ikke fast defineret proces er i centrum (Bager \& Blenker, 2008; Kirketerp, 2010; Krill, 2012).

Den konstruerende tilgang kan yderligere kobles til teorierne om situeret læring og praksisfællesskaber. Her betones individets samspil med sine omgivelser i kontekster, hvor de sociokulturelle faktorer spiller ind på den måde, man kan agere på i de sammenhænge, man indgår i (Lave \& Wenger, 1991; Wenger, 1998). Det medfører, at læring og innovationsundervisning altid foregår i en bestemt uddannelsesmæssig kontekst, og at de studerendes forskellige baggrunde og fagligheder aktivt kan bringes i spil i udviklingen af nye idéer. Samtidig udvider dette syn på læring det antal af kontekster, som man kan have fokus på i innovationsundervisning, idet teorierne tager højde for, at vi er præget af og indgår i mange sammenhænge, som man dermed kan inddrage i forløbet. 
Dette understøttes af teorier om transformativ medieret læring, hvor den lærendes meningsskabelse af tilegnet viden sættes i sammenhæng med personens generelle liv og kan bidrage til perspektivet på studerende som lærende i bred forstand, hvor også deres øvrige hverdagsliv kobles sammen med uddannelse. (Kritskaya \& Dirkx, 2000).

\section{Progression}

Progression handler om opbygning af læring, men der hersker forskellige forståelser af progression inden for forskellige fagområder. Eksempelvis kan progression anskues som en lineær og planlagt udvikling eller som en cirkulær proces alt efter hvilke læringsmål, der er knyttet til en given undervisning (Leth, 2008). Leth opererer med fire metaforer for progression: Henholdsvis byggesten, spiraler/cirkler, kurver og koordinatsystemer. Disse repræsenterer billedlige forklaringer på, hvordan man skaber progression i læring inden for forskellige fagområder og i forskellige faser i konkrete undervisningsforløb (Leth, 2008).

Inden for de humanistiske uddannelser og herunder uddannelserne på International Virksomhedskommunikation synes metaforerne spiralen og cirklen at matche måden, de studerende lærer på samt måden, man skaber progression på. Progressionen foregår ikke umiddelbart lineært men i både fremadskridende og tilbagevendende processer, hvor forskellige temaers kompleksitet øges over tid, og hvor de forskellige fag i en uddannelse ideelt set supplerer progressionen i andre fag. Konsekvensen af det cirkulære kan være, at progressionen ikke er tydelig for de studerende i et enkelt fag eller mellem fag i en uddannelse, hvorfor de ikke af sig selv umiddelbart kan koble fagelementer sammen til en større helhed og forståelse af en uddannelses samlede fagområde.

Biggs \& Collins anskueliggør i deres taksonomi en proces, hvor den studerende indledningsvist kun lærer mindre dele af et fag eller et emne, hvorefter progressionen foregår over tid ved at delene sættes sammen til helheder, hvis kompleksitet forstås og kan anvendes i flere sammenhænge (Biggs \& Collins, 1982).

I relation til innovationsundervisning er det interessant at se, hvorledes andre taksonomier inden for læring og progression opererer med et kreativt eller syntetisk kombinerende element i de øverste og mest komplekse former for progression i relation til læring. Eksempelvis udgøres det andet øverste trin i Blooms taksonomi af syntese, hvor den personlige bearbejdning af stoffet træder i kraft, og hvor kreative dimensioner af læringen opstår (Bloom, 1956). Anderson \& Krathwohl har videreudviklet på Blooms teori. I deres taksonomi er det øverste trin ekspliciteret som kreativitet og evnen til at tænke nyt (Anderson \& Krathwohl, 2001). Ligeledes har Bergman \& Steward kreativitet og nytænkning som deres øverste trin i deres arbejde med at tænke motivation ind i taksonomierne (Bergman \& Steward, 2006). Alle taksonomier forudsætter dog, at det kreative og syntetiske bygges oven på grundlæggende former for viden. 


\section{Innovation}

Ligesom begrebet progression kan innovation forstås på mange måder. Artiklens forståelse af innovation er knyttet til en dominerende, generel definition af entreprenørskab: "individets opdagelse, bearbejdning og udnyttelse af muligheder" (Shane \& Venkatamaran, 2000). Inden for innovationspædagogik læner man sig ofte op ad denne definition, idet den er bred og dermed åbner op for en tilgang til innovationsundervisning, der tillader mange typer af innovationer og processer i et læringsforløb hos studerende (Kirketerp, 2010; Darsø, 2011). Definitionen matcher desuden målet med det konkrete innovationsfag, hvor studerende skal udvikle, analysere og realisere innovative idéer.

Ordet 'opdagelse' kan erstattes med 'konstruktion' i en udbygget definition for at betone, at muligheder som idéer ikke allerede er derude og skal opdages, men at de konstrueres af mennesker jævnfør den konstruktivistiske tilgang. Samtidig kan individdimensionen fjernes for at gøre definitionen åben over for interaktionens betydning, hvilket er centralt, når man underviser teams. (Jensen, 2010; Jensen, 2011).

I det man kunne kalde en innovativ læreproces - konstruktion, bearbejdning og udnyttelse af muligheder - vil det innovative element indgå især i konstruktionen og udnyttelsen. Enten er selve muligheden - idéen - ny, eller også er måden, man udnytter muligheden på, ny. Innovation er derfor en metode eller et værktøj i læreprocessen. Innovationsteoretikeren Drucker udtrykker det således:

"Innovation is the specific tool of entrepreneurs, the means by which they exploit change as an opportunity for a different business or a different service."

(Drucker, 1985/1983, s. 17).

Drucker pointerer, at innovation er en systematisk metode, der kan tilegnes. Man analyserer sig frem til at forstå forandringer i samfundet for at kunne anvende sine analyser af forandringerne til at skabe nyt. Det betyder, at innovation kan betragtes som en bevidst arbejdsform, som dermed kan udmønte sig i et fag, hvor studerende skaber nyt gennem et fremadskridende forløb. Det syn på innovation har paralleller til progressionsbegrebet og taksonomierne, hvor der bygges oven på eksisterende viden med det formål at opnå kompleks, selvstændig eller syntetisk kompetence.

\section{Bred kompetenceafklaring i innovationsundervisning}

Artiklens omdrejningspunkt for en mulig forbindelse mellem progression og innovationsundervisning fokuserer på studerendes kompetencer i bred forstand som en løftestang for udvikling af nyskabende idéer og som en måde at øge progressionen i og mellem fag på en given uddannelse. 
Kompetencer forstås generelt som evnen til at omsætte viden og kvalifikationer, og kobles således til selve uddannelseskonteksten (Illeris, 2012). Dette understøttes af Undervisningsministeriets strategi for entreprenørskabsundervisning, hvor der efterlyses en fagdidaktik, der "på samme tid styrker den studerendes faglige kompetencer og evnen til innovativ anvendelse af fagligheden." (Undervisningsministeriet, 2006).

Dette er i sig selv en udfordring for underviser og studerende og kræver opmærksomhed: Hvis studerende skal udvikle nye muligheder på basis af faglighed, må man sikre, at de faktisk er sig fagligheden bevidst i form af svar på spørgsmål om: "hvad kan jeg i kraft af min uddannelse og de enkelte fag, som jeg læser?". Dette kan illustreres ved hjælp af Dreyfus \& Dreyfus' skema (Dreyfus \& Dreyfus, 1986) om bevidst/ubevidst kompetence og inkompetence:

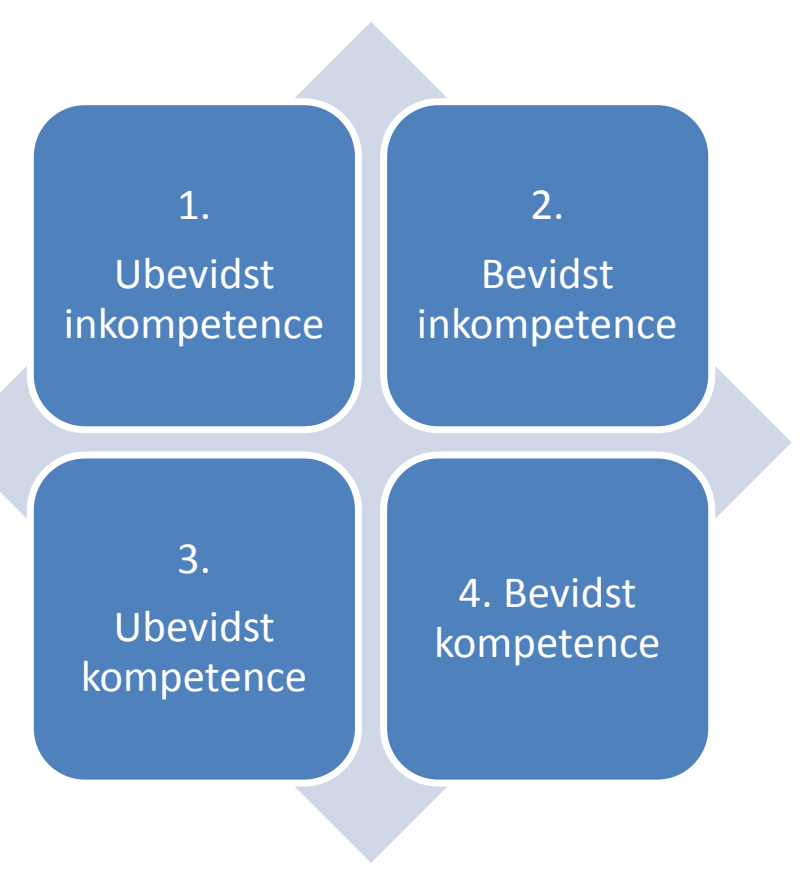

Modellen viser, hvorledes det er nødvendigt at bevæge de studerende fra felt 3 til 4 for at kunne åbne op for en aktiv anvendelse af den viden, færdigheder og kompetencer, som de har erhvervet sig i kraft af deres studie. Samtidig er det interessant, at data fra det obligatoriske innovationsfag indikerer, at de studerende ofte indledningsvist har en tendens til at befinde sig i felt 2, hvor de er bevidste om deres inkompetencer. De føler sig ikke kompetente til at kunne træde ind i fagets arbejdsform og anser ikke deres nuværende kompetencer fra de andre fag som betydningsfulde i dette fag. Ved indledende mundtlig kompetenceafklaring ytrer en del studerende, at de ikke kan se, hvordan deres faglighed og viden kan anvendes. Således ses en manglende oplevelse af progression i og mellem fag hos de studerende. Dette 
understøttes af undersøgelser af humanister, der påpeger, at de typisk ikke er bevidste om egne kompetencer (Riisager \& Herting, 2004; Fink et al., 2005).

Efterfølgende går de studerende igennem en kompetenceafklaring, hvor de får mulighed for at blive bevidste om disse elementer. Ved slutevalueringer for de tre år har mere end $50 \%$ af de studerende påpeget, at det er blevet tydeligere, at de har oparbejdet viden, som de kunne aktivere i innovationsfaget. Den indledende kompetenceafklaring er derfor en metode til at bevæge de studerende fra felt 2 og 3 til felt 4 i Dreyfus \& Dreyfus-modellen.

Flere betoner vigtigheden af, at man også innoverer ud fra generelle styrker og erfaringer (Drucker, 1985; Read et al., 2009; Darsø, 2011). Darsø anvender begrebet 'intrainnovativ' som udtryk for en metakompetence, hvor man gør sig bevidst om egne og andres forskellige typer af potentialer i nyskabelse af en mulighed (Darsø, 2011). En bredere tilgang til kompetenceafklaring kan således supplere med viden og erfaring, som de studerende henter fra andre steder end det rent faglige. På International Virksomhedskommunikation har man de sidste 2 år anlagt et bredere perspektiv på afklaring af studerendes kompetencer.

Selve metoden for afklaringen er inspireret af entreprenørskabsfeltet, hvor forskning har vist, at innovatører og entreprenører skaber nyt med udgangspunkt i de ressourcer og kompetencer, som de selv eller deres netværk er i besiddelse af (Sarasvathy, 2001; Read et al., 2009). Tilgangen beror på begrebet 'effectuation' som en modpol til 'causation' og betoner en mere emergent og ad hoc arbejdsform, der ikke tager udgangspunkt i lineær planlægning men i tilgængelige ressourcer - egne eller andres eller med Sarasvathys udtryk: 'The Bird-in-Hand Principle" (Sarasvathy, 2001). Princippet går ud på at stille tre overordnede spørgsmål i udviklingen og realiseringen af en mulighed: "Hvem er jeg, hvad ved jeg, og hvem kender jeg?" De tre dimensioner udgør tilsammen et bud på en metode indenfor innovations- og entreprenørskabsundervisning til at gøre studerende bevidste om deres ressourcer i udviklingsforløb (Read et al., 2009; Jensen, 2011; Lynfort, 2012).

Under spørgsmålet "hvem er jeg?" får studerende mulighed for at reflektere over deres uddannelsesmæssige fagidentitet og andre identiteter, som de bærer med sig. Det kan inspirere dem til at bruge deres uddannelse og erfaringer til at udvikle idéer, som de faktisk kan identificere sig med på det faglige og det mere personlige plan, hvilket kan øge deres oplevelse af sammenhæng.

Under spørgsmålet "hvad ved jeg?" får de sat fokus på viden fra de forskellige fag, de læser/har læst og de erfaringer, som de henter uden for universitetets kontekst. Dette aspekt hjælper dem til at forstå, hvilke specifikke værktøjer de kan anvende i arbejdet med idéen og give dem en forståelse af, at de ikke står på bar bund i arbejdet med idéen. 
Under det sidste spørgsmål "hvem kender jeg?" sættes fokus på en løbende afdækning af, hvilke personer, aktører eller organisationer, de studerende har adgang til som en del af deres netværk ud fra erkendelsen af, at man i innovative udviklingsforløb har behov for sparring og viden fra andre end en selv.

Når kompetenceafklaring kobles til 'effectuation', udvides arbejdet med at bevidstgøre de faglige kompetencer til at gælde for en persons hele liv og dennes netværk. Der sker således en bevægelse væk fra læring som et enkelt individs "ensomme" proces og en overskridelse af konteksten for læring fra uddannelsen til alle de kontekster, som en studerende kan indgå i, hvilket korresponderer med artiklens læringsteoretiske ståsted. De tre spørgsmål er nye for de fleste studerende. Derfor integreres kompetenceafklaringen i selve undervisningen i starten af forløbet, hvor de gennemgår personprofilanalyser og laver individuelle og holdbaserede afklaringsøvelser. Hver studerende udfylder en såkaldt kompetenceprofil, som de bærer med sig ind i teamsamarbejdet. Kompetenceprofilens skabelon er lavet ud fra bird-inhand princippet, og uploades på de studerendes elektroniske undervisningsplatform.

Nedenfor ses et skema, der viser, hvordan empiriske eksempler fra 70 kompetenceprofiler kan illustrere de studerendes afdækning af deres uddannelsesmæssige og erfaringsmæssige kompetencer under hvert af de tre 'effectuation'-principper. De anvendte værktøjer fra undervisningen er inkluderet. De studerende bruger kompetenceeksemplerne til at udvikle og analysere deres ideer.

\begin{tabular}{|c|c|c|}
\hline $\begin{array}{l}\text { 'Bird-in-hand'- } \\
\text { princippet }\end{array}$ & Kompetenceafklaring & Eksempler \\
\hline HVEM ER JEG? & $\begin{array}{l}\text { Uddannelse: } \\
\text { Egen refleksion og samtale om faglig- } \\
\text { hed/uddannelsesmæssig identitet } \\
\text { Erfaringer } \\
\text { Egen refleksion og samtale om personlig bag- } \\
\text { grund, øvrige identiteter } \\
\text { Værktøjer } \\
\text { I undervisningen anvendes personprofiltests og } \\
\text { øvelse med beskrivelse af 2-3 begivenheder eller } \\
\text { ting, der har formet den studerende som person }\end{array}$ & $\begin{array}{l}\text { "Jeg er flerfaglig", "jeg er } \\
\text { humanist", "jeg uddan- } \\
\text { ner mig indenfor kom- } \\
\text { munikation". } \\
\text { Identificerer sig som } 1 . \\
\text { generationsakademiker, } \\
\text { vokset op i storfamilie, } \\
\text { en ildsjæl, forældre er } \\
\text { iværksættere } \\
\text { Persontest viser, at den } \\
\text { studerende har et stort } \\
\text { drive, test viser behov for } \\
\text { fællesskab, sygdom i en } \\
\text { studerendes nære familie } \\
\text { har udviklet omsorgs- } \\
\text { gen, en lærer har troet på } \\
\text { sin elev og givet selvtillid }\end{array}$ \\
\hline
\end{tabular}




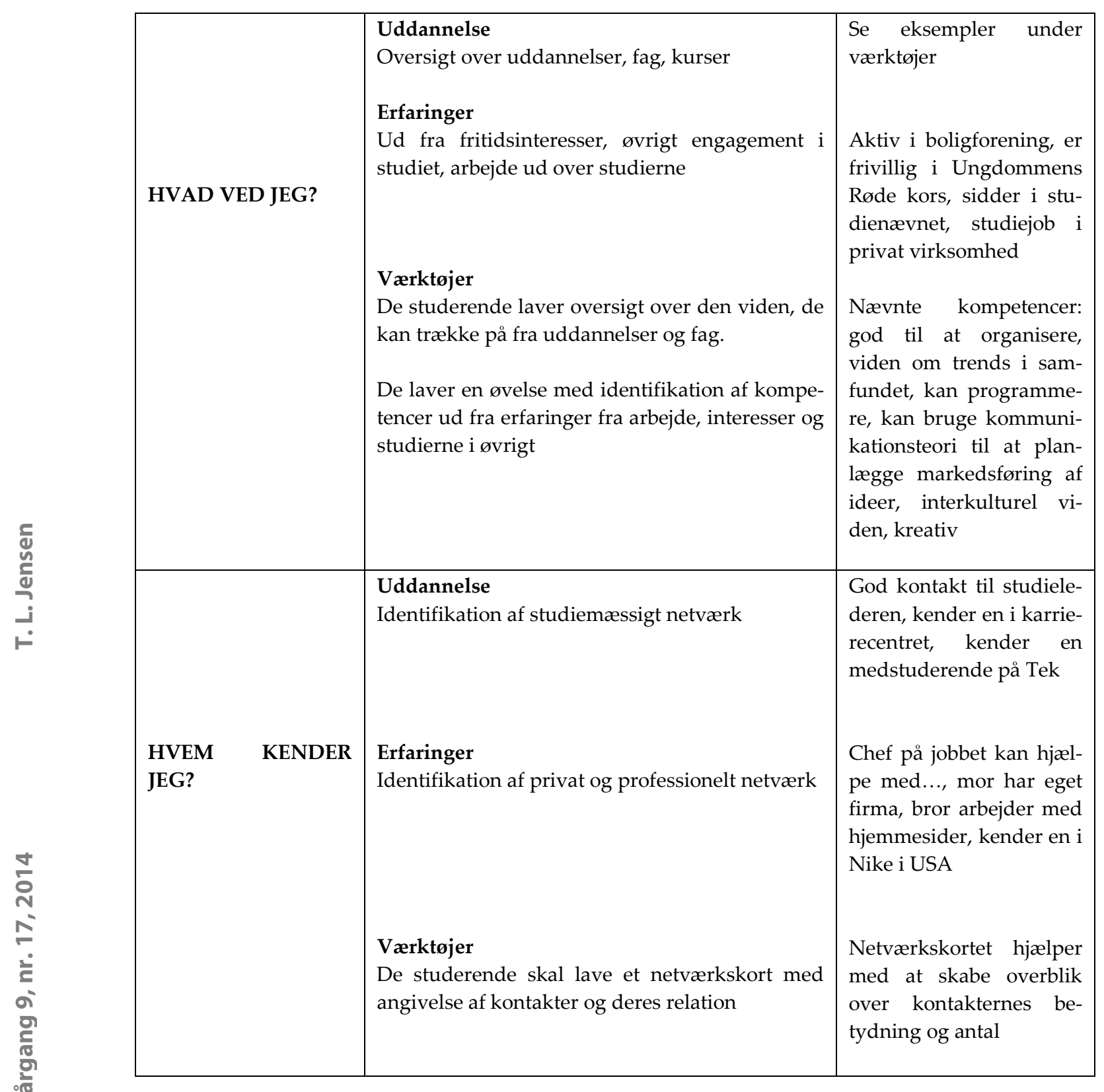

Skemaets formål er at vise, hvordan kompetenceafklaringselementer kan tænkes sammen i et innovationsforløb på Humaniora, og der er mange flere eksempler i de empiriske data, som det ikke er muligt at medtage her. Til trods for dette kan skemaet muligvis inspirere andre undervisere inden for innovation eller andre fagområder til at fokusere på, hvilken viden og hvilke erfaringer, studerende kan aktivere $i$ et givent fag på en given uddannelse.

Samtidig anvendes skemaet som afsæt til at videreudvikle en måde at arbejde med progression på i uddannelsessystemet. I det følgende præsenteres en model, der trækker på den brede tilgang til kompetencer og sammenhæng i, mellem og ved siden af fag. 


\section{En progressionsmodel}

Ud fra idéen om, at progression både kan oparbejdes i et enkelt fag, mellem fag og uden for fag, bygges modellen op omkring disse tre parametre. Progression anskueliggøres på tre skalaer i henholdsvis et konkret fagligt forløb (den singulære), mellem fag på en uddannelse (den flerfaglige), og ved et fokus på fagets og uddannelsens forbindelser til andre kontekster, der kan bidrage til udvikling og læring i et fag (den holistiske). Samtidig opererer modellen med to former for progression: Intenderet progression som de elementer, en underviser kan placere på de tre skalaer og oplevet progression som det, de studerende kan få ud af at arbejde på denne måde (Krogh \& Nielsen, 2011).

Til den singulære skala kobles nye teorier og metoder, som direkte vedrører et fags mål og indhold. Her handler progression om at lære nyt fagstof. Under den flerfaglige progression integreres viden, færdigheder og kompetencer fra andre fag i undervisningsforløbet initieret af underviseren gennem kompetenceafklaring. Herefter kan de studerende opleve en sammenhængende progression, hvor de overfører elementer fra andre fag i deres uddannelse. Ved den sidste skala, den såkaldte holistiske progression, kan underviseren arbejde med at gøre de studerede bevidste om de ressourcer, der findes i deres omgivelser og som generel viden og erfaring hos dem selv. Denne helhedssammenhæng mellem fag, uddannelse og hverdagsliv kan give både studerende og progressionsbegrebet nye betydninger og nye muligheder. I relation til Biggs \& Collins taksonomi kan modellen ses som et udtryk for, at de studerende guides $\mathrm{i}$ arbejdet med at anskueliggøre de mange forskellige delelementer, som deres viden består af, og som de kan kombinere.

I modellen refereres til et innovationsfag, da det er artiklens fagdisciplinære område. I princippet kan elementerne og værktøjerne skiftes ud alt efter fag. Modellen er endnu ikke taget $\mathrm{i}$ anvendelse $\mathrm{i}$ et undervisningsforløb og er således en teoretisk udledning af de foregående pointer i artiklen. Den bygger videre på skemaet, hvor 'effectuation' og 'kompetenceafklaring' er koblet sammen. Antagelsen er, at der ligger et læringspotentiale hos studerende ved at tænke alle tre former for progression ind $\mathrm{i}$ et undervisningsforløb, og at progression kan begrebsliggøres som mere end uddannelseskonteksten. 


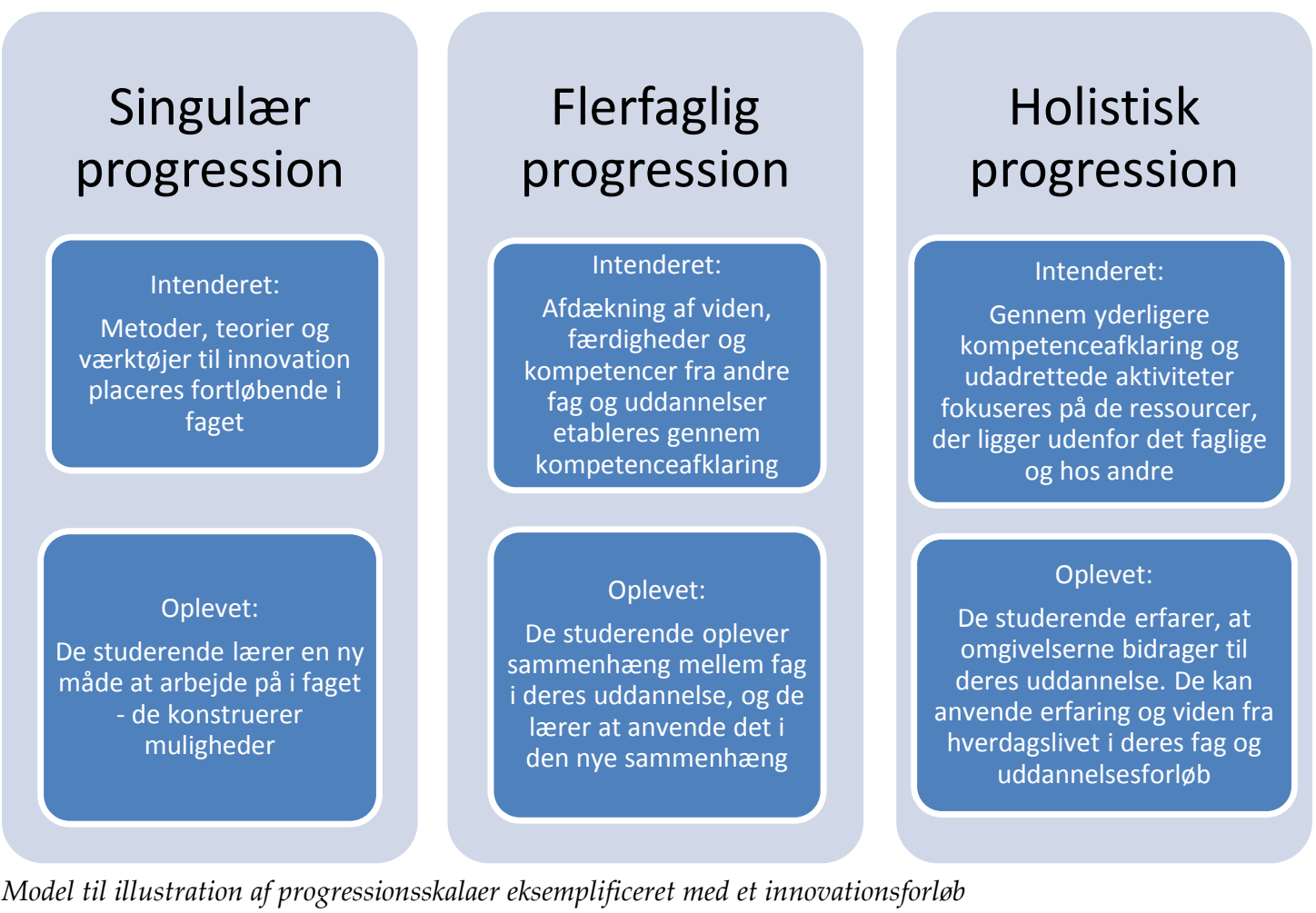

\section{Anvendelsesmuligheder og opsamling:}

De muligheder, der ligger i at arbejde med progression gennem kompetenceafklaring - her med afsæt i innovationsfag - i uddannelsessystemet, åbner op for en udvidelse af synet på progression i teori og praksis. Tilgangen beskriver, hvordan man kan arbejde bredere med begrebet, idet den underviserinitierede kompetenceafklaring bidrager til at skabe opbygning og sammenhæng i, mellem og uden for fag. Den flerfaglige og især den holistiske progressionsskala transcenderer desuden det enkelte fag og opfordrer til øget samarbejde mellem undervisere og til studerendes kobling af fag til livet uden for uddannelseskonteksten. Formålet er at lære studerende at trække etableret viden, færdigheder og kompetencer med sig gennem en uddannelse.

Ligeledes kan der - sådan som titlen foreslår det - opstå innovation gennem progression. Ved at anvende kompetenceafklaring i singulær, flerfaglig og holistisk progression kan innovationsundervisere give de studerende et bredere grundlag at udvikle nyt på. Et bevidst fokus på at øge progressionen i innovationsfag kan bidrage til at legitimere den nye innovationsbølge, som ruller ind over uddannelsessystemet i disse år, idet innovationsfag etablerer forbindelser til de øvrige fag på uddannelserne.

Artiklens hovedbudskab er, at progression og innovation kan berige hverandre $\mathrm{i}$ uddannelsessystemet, og at der er potentiale $\mathrm{i}$ at forbinde de to begreber ved at bryde grænserne mellem fag, universitet og omverden gennem kompetenceafklaring. 
Tine Lynfort Jensen har gennem 8 år varetaget undervisningen $i$ Innovation og Entreprenørskab på uddannelserne under International Virksomhed på Humaniora på Syddansk Universitet. Forfatteren har en uddannelsesmæssig baggrund inden for Filosofi, Virksomhedskommunikation og Organisationsstudier, og har arbejdet med personaleledelse og -udvikling $i$ den private sektor inden hun blev ansat ved Syddansk Universitet. Fagligt fokuserer forfatteren på måden, innovations - og entreprenørskabsundervisning påvirker studerendes faglighed og identitet på, ligesom kompetenceafklaring udgør en del af arbejdet med studerende i undervisningen. Endelig interesserer hun sig for den måde, som læringsteorier og læringsforståelser udvikler sig på i takt med introduktionen af innovative fag på universiteterne.

\section{Litteratur}

Anderson, L.W. \& Krathwohl, D.R. (red) (2001). A Taxonomy for Learning, Teaching and Assessing: A Revision of Bloom's Taxonomy of Educational Objectives. New York: Longman.

Bager, L. \& Blenker, P. (2008). Bevidsthed om læring - en kompetence med udgangspunkt i entrepreneuriel undervisning. I: H. Leth (2008): Bevidsthed om læring $i$ uddannelserne: progression, portfolio og entrepreneurship. Århus: Center for Undervisningsudvikling.

Bergman, T. \& Steward, H. (2006). Bloom's Cognitive and Affective Taxonomies. Netudgivelse: www.mehs.educ.state.ak.us

Biggs, J. \& Collins, K. (1982). Evaluating the Quality of Learning: the SOLO Taxonomy. New York: Academic Press.

Bloom, B.S. (1956). Taxonomy of Educational Objectives, The Classification of Educational Goals. New York: David McKay \& Co.

Darsø, L. (2011). Innovationspædagogik. Frederiksberg: Samfundslitteratur.

Dreyfus, H. \& Dreyfus, S. (1986). Intuitiv ekspertise. København: Munksgaard.

Drucker, P. (1985). Innovation and Entrepreneurship. New York: Harper \& Row.

Fink H. et al. (2005). Humanistisk viden $i$ et vidensamfund. København: Forskningsrådet for Kultur og Kommunikation.

Frølund, S. et al. (2009). Humaniora - Erhvervslivets nye grundstof. København: Gyldendal.

Hughes, M. (red.) (1996). Progression in learning. Avon, UK: Multilingual Matters Ltd. Kirketerp, A. (2010). Foretagsomhedsdidaktik - Skubmetoden. I: Kirketerp \& Greve (red.): Entreprenørskabsundervisning. Århus: Aarhus Universitetsforlag.

Krill, C. (2012). Entreprenørskab og innovation - nye fag og nye læringsmål kræver nye undervisningskompetencer. I: Reflexen. Tidsskrift for uddannelser ved institut for læring og filosofi, Aalborg Universitet, 7(2).

Kritskaya, O. \& Dirkx, J. (2000). Mediating Meaning-Making: The Process of Symbolic Action in Transformative Pedagogy. I: Proceedings of the 41st Annual Adult Education Conference.

Krogh, E. \& Nielsen, F. V. red (2011). Sammenlignende fagdidaktik. Århus: Aarhus Universitet. 
Lave, J. \& Wenger, E. (1991). Situated Learning: Legitimate Peripheral Participation. Cambridge: University of Cambridge Press.

Leth, H. (red.) (2008). Bevidsthed om lxring i uddannelserne: progression, portfolio og entrepreneurship. Århus: Center for Undervisningsudvikling.

Jensen, T. L. (2010). “Who can become an entrepreneur?" - er et godt spørgsmål. En analyse af humaniorastuderende og entrepreneurship education. Ph.d.-afhandling fra Syddansk Universitet.

Jensen, T. L. (2011). Operationen lykkes, hvis studenten overlever,, i Kirketerp \& Greve, red (2011): Entreprenørskabsundervisning. Århus: Aarhus Universitetsforlag.

Lynfort, T. (2012). Effectuation i den entreprenante læreproces blandt humaniorastuderende. Fonden for Entreprenørskab, Odense

Ministeriet for Videnskab, Udvikling og Teknologi, Kulturministeriet, Undervisningsministeriet \& Økonomi - og Erhvervsministeriet (2010). Strategi for uddannelse i entreprenørskab. København.

Ministeriet for Forskning, Innovation og Videregående Uddannelser (2012). Innovationsstrategien: Danmark - Løsningernes Land. København.

Ministeriet for Forskning, Innovation og Videregående Uddannelser (2013). Notat om frafald på de videregående uddannelser. København.

Qvortrup, A. \& Wiberg, M (red.) (2013). Læringsteori og Didaktik. København: Hans Reitzels Forlag.

Read, S. et al. (2009). Effectual Entrepreneurship. New York: Routledge.

Riisager, M. \& Herting, S. (2004). Kompetencer I Spil. København: Københavns Universitet.

Sarasvathy, S. D. (2001). Causation and Effectuation: Toward a Theoretical Shift From Economic Inevitability to Entrepreneurial Contingency. Academy of Management Review, 26(2), 243-263.

Shane, S. \& Venkataraman, S. (2000). The promise of entrepreneurship as a field og research. Academy of management Review, 25(1).

Undervisningsministeriet (2006). Entreprenørskabsundervisning. Rapport udgivet på ministeriets hjemmeside.

Wenger, E. (1998). Communities of Practice. Cambridge: Cambridge University. 